\title{
Pemanfaatan Limbah Nikel Sorowako Dalam Campuran Stone Matrix Asphalt Kasar Febe Priskila Supit ${ }^{* 1}$ Robert Mangontan $^{* 2}$, Alpius $^{* 3}$
}

\author{
*1 Mahasiswa Program Studi Teknik Sipil, Universitas Kristen Indonesia Paulus, Makassar, Indonesia \\ Febepriskilasupit@gmail.com \\ *2,3 Dosen Program Studi Teknik Sipil, Universitas Kristen Indonesia Paulus, Makassar, Indonesia \\ robert mangontan@gmail.com dan alpiusnini@gmail.com
}

\begin{abstract}
ABSTRAK
Perkembangan perindustrian di Indonesia sangat pesat dan memberi dampak yang baik bagi perekonomian suatu daerah atau negara. Namun dampak buruk yang dapat ditimbulkan dari hasil perindustrian tersebut adalah limbah dengan jumlah yang sangat banyak dan tidak dimanfaatkan untuk suatu kegiatan yang bermanfaat bagi suatu daerah. Tujuan penelitian ini adalah melakukan pengujian untuk mengetahui Pemanfaatan Limbah Nikel Sorowako Dalam Campuran Stone Matrix Asphalt Kasar dengan menggunakan variasi kadar aspal 6,00\%; 6,25\%;6,50\%;6,75\% dan 7,00\% dan menguji kemampun campuran bahan tersebut terhadap waktu lamanya prendaman, suhu, dan air. Metode yang digunakan adalah dengan melakukan berbagai pemeriksaan dan pengujian spesifik mengenai agregat lalu merancangkan struktur campuran SMA kasar dan juga pemeriksaan marshall untuk memperoleh karakteristik campuran serta pemeriksaan marshall immertion untuk mendapatkan nilai stabilitas Marshall sisa dengan menggunakan kadar aspal optimum. Dari hasil penelitian ini diketahui bahan berupa Limbah Nikel memenuhi standar syarat Umum, Bina Marga 2018, dan dapat di gunakan sebagai bahan, campuran perkerasan jalan. Kadar aspal yang digunakan pada pengujian Marshall SMA kasar adalah 6,00\%, $6,250 \%, 6,50 \%, 6,75 \%, 7,00 \%$. Nilai marshall immertion dengan nilai KOA ialah 7,00\% dan didapatkan nilai stabilitas marshall sisa 95,55 \% yang telah memenuhi syarat Spesifikasi Umum Bina Marga 2018 yaitu 90\%.
\end{abstract}

Kata Kunci : Pemanfaatan, limbah, agregat, Stone Matrix Asphalt.

\section{ABSTRACT}

Industrial development in Indonesia is very rapid and has a good impact on the economy of a region or country. However, the negative impact that can be generated from the industrial output is waste in a very large amount and not used for an activity that is beneficial to an area. The purpose of this study was to conduct tests to determine the utilization of Sorowako nickel waste in coarse asphalt stone matrix mixtures by using a variation of asphalt content of $6.00 \% ; 6.25 \% ; 6.50 \% ; 6.75 \%$ and $7.00 \%$ and tested the efficacy of the mixture against the duration of immersion, temperature, and water. The method used is to perform various examinations and specific tests regarding the aggregate and then design the structure of the coarse SMA mixture and also the marshall examination to obtain the characteristics of the mixture and the marshall immertion examination to obtain the residual Marshall stability value using the optimum bitumen content. From the results of this study, it is known that the material in the form of nickel waste meets the standard requirements of the General Bina Marga 2018, and can be used as a mixture of road pavement. The asphalt content used in the Marshall SMA rough test was $6.00 \%, 6.250 \%, 6.50 \%, 6.75 \%, 7.00 \%$. The marshall immertion value with a KOA value is $7.00 \%$ and the remaining marshall stability value is $95.55 \%$ which has met the requirements of the 2018 Highways General Specification, which is $90 \%$.

Keywords: Utilization, waste, aggregate, Stone Matrix Asphalt

\section{PENDAHULUAN}

Perkembangan perindustrian di Indonesia sangat pesat dan memberi dampak yang baik bagi perekonomian suatu daerah atau negara. Namun dampak buruk yang dapat ditimbulkan dari hasil perindustrian tersebut adalah limbah dengan jumlah yang sangat banyak dan tidak dimanfaatkan untuk suatu kegiatan yang bermanfaat bagi suatu daerah.

Limbah merupakan hasil pembuangan suatu industri yang kurang bernilai ekonomis dan berdampak buruk bagi lingkungan apabila tidak dapat dikelola dengan sebaik mungkin [1] [2]. Hal ini menjadikan limbah sebagai masalah serius yang perlu diatasi, sehingga diharapkan dapat 
Paulus Civil Engineering Journal

E- Jurnal Teknik Sipil UKI-Paulus Makassar

http://ojs.ukipaulus.ac.id/index.php/pcej
Volume 3 No.1, Maret 2021

ISSN Online 2775-4529 mengurangi efek pencemaran yang ditimbulkan bagi masyarakat.

Salah satu industri terbesar di Sorowako, Kabupaten Luwu Timur adalah PT Vale Indonesia, Tbk. Yang mengolah nikel. Dari pengolahan nikel tersebut menghasilkan limbah atau slag dalam jumlah yang cukup banyak dan terus bertambah seiring dengan produksi yang meningkat. Oleh sebab itu diperlukan pengolahan yang tepat bagi limbah nikel atau slag tersebut. Limbah Nikel atau slag merupakan bahan sisa industri hasil peleburan atau pembakaran biji Nikel dengan suhu yang sangat tinggi. Bentuk slag secara visual menyerupai agregat. digunakan sebagai bahan timbunan atau dibuang dan tidak dimanfaatkan sehingga kurang bernilai ekonomis.

Limbah nikel atau slag tersebut memiliki kandungan besi, karena slag tersebut adalah hasil dari pembakaran biji nikel yang mengandung besi kemudian mengalami korosi dan akan terbawa dalam slag. Oleh sebab itu slag nikel memiliki keunggulan dapat menahan panas lebih lama.

Pada penelitian ini, limbah nikel akan digunakan sebagai bahan pengganti agregat pada lapisan perkerasan jalan, khususnya pada campuran Stone Matrix Asphalt (SMA) Kasar.

Penggunaan bahan sisa berupa slag nikel sebagai bahan pengganti aggregat kasar pada campurn Stone Matrix Asphatl Kasar adalah salah satu alternatif atau solusi yang bisa digunakan untuk pengadaan material agregat kasar yang secara ekonomis diharapkan dapat mengurangi dampak negatif yang mungkin akan ditimbulkan seperti pencemaran lingkungan.

Penggunaan limbah nikel atau slag nikel dari Sorowako, Kabupaten Luwu Timur, belum diteliti secara spesifik mengenai agregat dalam campuran Stone Matrix Asphalt (SMA) Kasar.

Peneitian yang pernah dilakukan tentang pemanfaatan limbah slag nikel antar lain, Manguma (2020) meneliti tentang pengaruh penggunaan slag nikel terhadap indeks kekuatan sisa campuran HRS-WC [3]. Kamba \& Rachman (2018), Pengujian Karakteristik Marshall Pada Camputan HRS Gradasi Semi Senjang menggunakan Slag Nikel [4]. Kusuma \& Rachman (2018) Study Karakteristi Slag Nikel pada campuran HRS-Base gradasi semi senjang [5]. Demmalino at.al. 2019, meneliti tetntang pengujian slag nikel sebagai pengganti agregat pada campuran HRS-Base [6]. Sedangkan penelitian penggunaan limbah lainnya antara lain [7]. Datu at,al. 2019, meneliti tentang The Effect of Additional Sugar Palm Fibers on the Durability of Mixed Laston AC-WC [8]. Tandibua at.al (2020) meneliti tentang Study of Laston BC Durability and Permeability Using Coconut Shell Addition

Materials [9]. Alpius (2018) meneliti tentang Effects of Additional Rattan Fiber on Hot Rolled Sheet Wearing Course (HRS-WC) Stability [10].

Tujuan penelitian ini adalah melakukan pengujian untuk mengetahui Pemanfaatan Limbah Nikel Sorowako Dalam Campuran Stone Matrix Asphalt Kasar dengan menggunakan variasi kadar aspal $6,00 \% ; 6,25 \% ; 6,50 \% ; 6,75 \%$ dan $7,00 \%$ dan menguji kemampun campuran bahan tersebut terhadap waktu lamanya prendaman, suhu, dan air.

\section{METODE PENELITIAN 1. Lokasi Pengambilan Material}

Lokasi pengambilan material di PT Vale Indonesia Tbk, Sorowako berjarak 40 km dari lbu Kota Malili Kabupaten Luwu Timur Lokasi penelitian dapat lihat pada gambar 1.

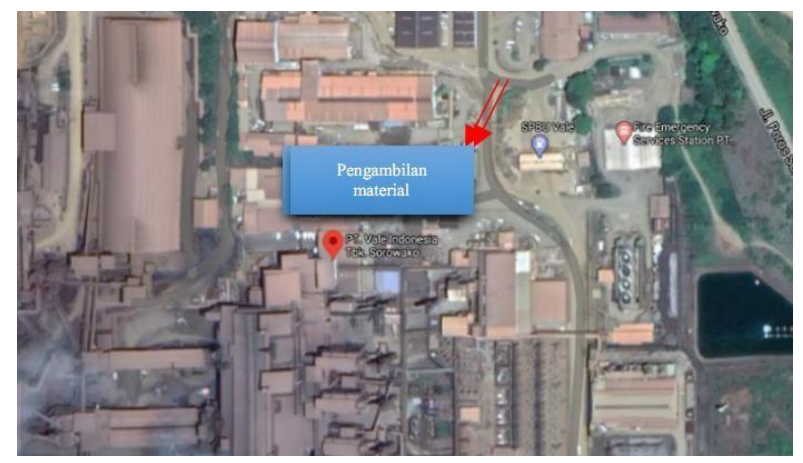

Gambar 1. Lokasi pengambilan material 2.

\section{Pemeriksaan agregat}

Pemeriksaan agregat didasarkan pada SNI yang ditentukan dalam Spesifikasi Bina Marga 2018 [11]

Pengujan Keausan (Abrasion) dengan Mesin Los Angles (SNI 2417;2008). Percobaan ini memiliki tujuan untuk melihat tingkap ausan agregat menggunakan mesin los angles dengan perbandingan berat benda yang lolos saringan No.12 $(1,7)$ dengan berat semula, dalam \%.

Pemeriksan berat jenis curah (Bulk) dan penyerapan air aggregat kasar (SNI 1969:2016). 
Paulus Civil Engineering Journal

E- Jurnal Teknik Sipil UKI-Paulus Makassar

http://ojs.ukipaulus.ac.id/index.php/pcej

Dan agregat halus (SNI 1970:2016). Tujuan dari pemeriksaan beras jenis curah ini ialah untuk menentukan nilaiberat jenis dan penyerapan pada agregat kasar sesuai dengan berat jenisnya.

Analisa saringan (SNI ASTM C136:2012) maksud dari pengujian Ini adalah mendistribusikan ukuran pada aggregat kasar kedalam bentuk grafik dan memperlihatkan gradasi ukuran agregat pada masing-masing saringan yang digunakan.

Pengujian Agregat lolos Ayakan No.200 / 0,075; mm (SNI ASTM C117;2012). pemeriksaan Ini untuk melihat hasil presentase bahan pada agregat yang lolos saringan nomor 200 / 0,075 mm sehinga berguna bagi perencana dan pelaksana pembanguan jalan.

Pemeriksan Nilai Setara Pasir (SNI 03-4428-1997) tujuan pada percobaan Ini adalah untuk mengukur persentase kader lumpur pada aggregat halus.

Pengujian, kepipihan, dan kelonjongan (ASTM D4791-10) ialah untuk mendapatkan indeks kepipihan dan kelonjongan pada aggregat dan dinyatankan dalam persen (\%).

Pengujian kelekatan Afgregat terhadap aspal (SNI 2439:2011) pengujian ini merupakan hasil dari presentase banyaknya aspal yang menutupi permukaan batuan.

\section{Pemeriksaan Karakteristik Aspal}

Pada penelitian ini menggunakan metode pengujian penetrasi suhu 25oC (SNI 06-24562011) tujuannya adalah mengetahui tingkat kekuatan pada asphalt dengan melihat jarum yang masuk kedalam pada suhu dan waktu yang telah ditentukan.

Pengujian daktilitas pada 25oC (SNI 2432;2011). Maksut penelitian ini adalah untuk melihat kekenyalan aspal yang dinyatakan dengan panjang pemuluran aspal yang dapat tercapai hingga sebelum putus.

Pemeriksaan titik lembek (oC) (SNI 2434 : 2011) tujuannya adalah untuk melihat pada suhu berapa aspalnya mulai menjadi lembek.

Pengujiian titik nyala $\left({ }^{\circ} \mathrm{C}\right)$ (SNI 2434:2011) betujuan untuk mengetehui pada suhu berapakan akan muncul nyala api pada benda yang diuji.
Volume 3 No.1, Maret 2021

ISSN Online 2775-4529
Pengujian berat jenis aspal ( SNI 06- $2441:$ 2011). Pengujian ini bertujuan untuk melihat berat jenis pada benda yang dipakai.

Pengujian berat jenis yang hilang (\%) ( SNI 062441 : 1991) pemeriksaan Ini dilakukan untuk menentukan banyaknya minyak yang hilang opada aspal yang disebabkan dari pemanasan berulang serta untuk mengetahui perubahan kinerja yang terjadi akibat kehilangan berat pada aspal.

\section{Pemeriksaan berat jenis filler}

Pemeriksaan beret jenis filler (SNI ASTM C1362012) pemeriksaan tersebut bertujuan agar menentukan berat filler yang akan dipakai sebagai pengisi campuran beraspal.

\section{Perencanaan campuran}

Perencanaan Campuran untuk Stone Matrix Asphalt (SMA) yang dipakai adalah dengan menggunakan metode analisis dan grafis dalam bentuk table pada setiap batasan spesifikasi gradasi tersebut [12].

Tabel 1. Komposisi Campuran

\begin{tabular}{|c|c|c|c|c|c|}
\hline \multicolumn{2}{|c|}{ Ukuran saringan } & \multicolumn{4}{|c|}{ Lolos Saringan } \\
\hline Inchi & $\mathrm{Mm}$ & & $\begin{array}{c}\text { Spesifikasi } \\
(\%)\end{array}$ & & $\begin{array}{c}\text { Gradasi } \\
\text { Campuran }\end{array}$ \\
\hline $11 / 2 "$ & 37.500 & & & & \\
\hline $1 "$ & 25.000 & & & & \\
\hline $3 / 4 "$ & 19.000 & & 100 & & 100 \\
\hline $1 / 2 "$ & 12.500 & 90 & - & 100 & 95 \\
\hline $3 / 8 "$ & 9.500 & 50 & - & 80 & 65 \\
\hline No.4 & 4.750 & 20 & - & 35 & 27.5 \\
\hline No.8 & 2.360 & 16 & - & 24 & 20 \\
\hline No.16 & 1.180 & & - & & \\
\hline No.30 & 0.600 & & - & & \\
\hline No.50 & 0.300 & & - & & \\
\hline No.100 & 0.150 & & & & \\
\hline No.200 & 0.075 & 8 & - & 11 & 9.5 \\
\hline
\end{tabular}

\section{Komposisi campuran}

Setelah semua bahan yang di perlukan memenuhi spesifikas tahapan selanjutnya adalah menghitung komposisi campuran dan jumlah benda uji.

Perhitungan kadar aspal perkiraan awal:

Kadar aspal efektif $\min =6 \%$ Kadar aspal efektif maks $=7 \%$ maka rencangan kadar aspal yang di 
Paulus Civil Engineering Journal

E- Jurnal Teknik Sipil UKI-Paulus Makassar

http://ojs.ukipaulus.ac.id/index.php/pcej

gunakan untuk campuran adalah $6 \%, 6,25 \%, 6,50 \%, 6,75 \%$ dan $7 \%$ dengan kenaikan $0.25 \%$.

Berdasarkan Perhitungan kadar aspal perkiran awal untuk gradasi agregat gabungan diatas maka didapakan komposisi campuran beserta proporsi FIller nya seperti pada tabel 2.

Table 2. Komposisi Campuran

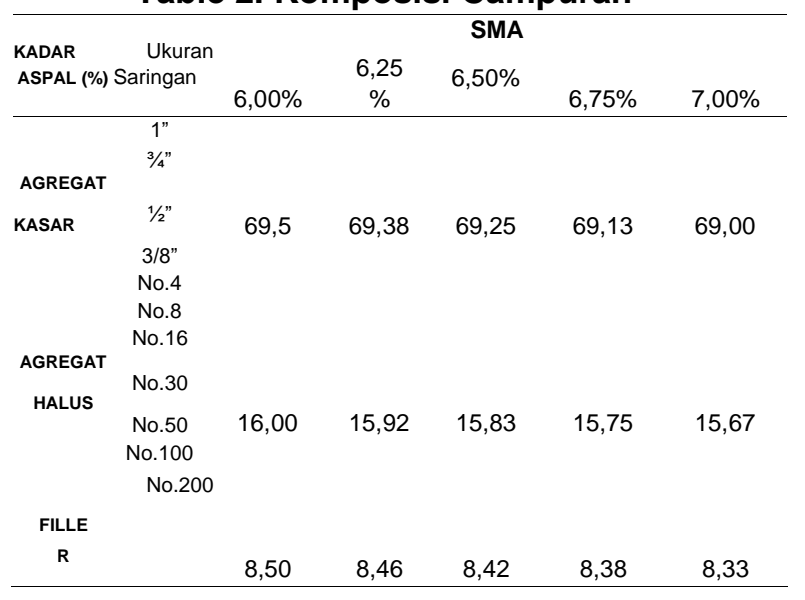

Tabel 3. Jumlah Benda Uji

KADAR ASPAL (\%) MARSHALL KONVENSIONAL MARSHALL

$\begin{array}{ccc}6,00 & 3 \\ & \\ 6,25 & 3 & \\ 6,5 & 3 & 3 \\ 6,75 & 3 & \\ 7,00 & 3 & \end{array}$

\section{Pengujian Marshall Konvensional}

Pada penelitian ini dilakukan Pengujian Marshall Konvensional agar dapat diketahui nilai ketahanan, nilai stabilitas serta nilai kelelehan, dan juga analisa kepadatan serta pori dalam campuran padat. Parameter pengujian Marshall yang di hitung antara lain: Stabilitas, VIM, VMA, dan Flow sesuai spesifikasi campuran. kemudian semua parameter beriket diperoleh, maka mengambarkan grafik hubungan kadar aspal dengan parameternya yang kemudian dapat ditentukan kadar aspal optimal [12].
Volume 3 No.1, Maret 2021

ISSN Online 2775-4529

\section{Penentuan Kadar Aspal Optimum}

Penentuan Kadar; Aspal Optimum diperoleh dari nilai tertingi pada grafik hubungn VIM, kepadatan campuran yang dipadatkan dengan kadar aspal. Untuk kadar aspal optimum maka pada campuran Stone Matriks Asphalt Kasar nilai VIM terkecil, karena lapisan stone matriks asphalt merupakan lapis permukaan yang harus kedap terhadap air untuk melindungi lapisan dibawahnya [12].

\section{Pengujian Marshall Immersion}

Pada penelitian Ini Pengujian Marshall Immersion (SNI 06-2489-1991). Maksud dari penguian ini ialah untuk melihat kemampun campuran bahan tersebut terhadap waktu lamanya prendaman, suhu, dan air. atau stabilitas marhall sisa [12].

\section{ANALISA DAN PEMBAHASAN 1. Karakteristik Material a. Agregat}

Pada penelitian ini di peroleh hasil pengujian kausan agggregat Alat Abrasi los Angles, didapatkan nilai ketahanan agregat kasar terhadap keausan dari Fraksi(A) adalah 3,08\%, Fraksi(B) adalah 3,02\%, Fraksi(C) adalah $3,28 \%$ dan Fraksi(D) adalah 3,42\%. Dari semua hasil pengujian, nilai maks 3\%. Dari Hasil pemeriksaan tentang berat jenis; dan penyerapan aggregat kasar yang menggunakan dua(2) sampel, didapatkan nilai Berat Jenis Bulk adalah 2,62 , berat jenis (SSD) adalah 2,65, berat jenis semu adalah 2,69 dan Penyerpan Air adalah 0,96\%. Hasil dari pemeriksaan berat jenis; dan penyerapan; aggregat halus, di dapatkan nilai untuk Berat Jenis Bulk adalah 2,56; Berat Jenis SSD adalah 2,5; Berat Jenis Semu adalah 2,62 dan Pnyerapan Air adalah 0,91\%.

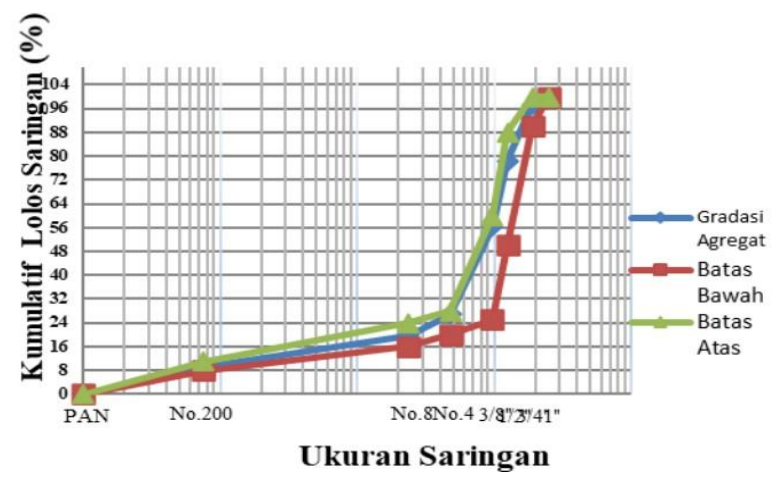

Gambar 2. Hasil pengujan analisa saringan

Setelah dilakukannya pengujian material lolos saringan No. 200 didapatkan hasil 0,7 dengan syaratan ialah maksimum 10\%. Dapat 
Paulus Civil Engineering Journal

E- Jurnal Teknik Sipil UKI-Paulus Makassar

http://ojs.ukipaulus.ac.id/index.php/pcej

disimpulkan pengujin Ini menunjukan material ini bersih dari lempung dan lanau.

Pada pemeriksaan Kadar lumpur Aggregat Halus mengunakan 2(dua) sampl didapatkan rata-rata nilai Sand Equivalent (SE) adalh 97,80\% dan kadar lumpur $2,20 \%$. Pengujian tersebut memenuhi syarat ialah minimal $50 \%$ untuk SandEquivalent serta maksimal 5\% untuk kadar lumpur.

Pada pemeriksaan Partikel Kepipinan dan Kelonjongan Aggregat Kasar di dapatkanh partikel pipih yaitu 4,86\%;3,63\%;4,86\%;0\%. Partikel lonjong yaitu $4,83 \%, 4,35 \%, 3,45 \%$ dan $0 \%$. Dengan syaratan yaitu maksimal $5 \%$.

Pada penelitian ini dilakukan uji Kelekatan Agregat pada Aspal. Hasilnya di tentukan dari luas permukan sampel yang tertutup aspal (kurang dari 95\% atau lebih dari 95\%). Jadi pengjian Ini di ketahui aspal bisa melekat pada aggregat[5].

\section{b. Aspal}

Pada penelitian ini aspal dapat dugunakan adalah aspal pernetrasi $60 / 70$. nilai penetrasi didapatkan dari hasil nilai penetrasi $66,7 \mathrm{~mm}$. syaratan yaitu min $60(0,1) \mathrm{mm}$ sampai maks $70(0,1) \mathrm{mm}$ Dari hasil penujian daktilitas di dapat kan nilai rata-rata 150 $\mathrm{cm}$. Persyaratan hasil pengujian rata-rata daktalitas ialah minimum $100 \mathrm{~cm}$. Hasil penguian titik lembek aspal di dapatkan nilai ratarata $50,2^{\circ} \mathrm{C}$ pesyaratan yaitu minimum $48^{\circ} \mathrm{C}$. Hasil pengujian Titik Nyala di dapatkan niai rata - rata 2900C. Syarat yang ditentukan dalam dalam Spesifikasii Umum Bina Marga 2018 yaitu Min $232^{\circ} \mathrm{C}$. Hasil Pengujian Berat Jenis didapatkan nilai rata-rata 1,051. persyaratan yaitu Min 1,0. Hasil pengujian, penurunan berat aspal didapatkan nilai rata-rata $0,434 \%$ di mana; persyartan Maks $0,8 \%$. Hasil pengujiian peneterasi padahasil berat aspal di dapatkan nilai rata -rata $84,7 \%$.

\section{Marshall Konvensional}

Bendauji di buat dengan kadar aspal untuk Campuran Stone Matrix Asphalt yaitu: 6,00\%; 6,25\%;6,50\%;6,75\%;7,00\%[6]. Hasiil perhitungan bulk spesific gravity dan effective spesific gravity dapat dilihat pada Tabel 4.

Tabel 4. Bulk Spesifc Gravitty Efective Spesific

\begin{tabular}{lcrlrl}
\multicolumn{5}{c}{ Gravity } \\
\hline \multicolumn{5}{c}{ CAMPURAN } & ITRIX ASPHA \\
KADAR ASPAL \% & $6,00 \%$ & & & & \\
& & $6.25 \%$ & $6,50 \%$ & $6,75 \%$ & $7,00 \%$
\end{tabular}

Volume 3 No.1, Maret 2021

ISSN Online 2775-4529

\begin{tabular}{lccccc}
\hline $\begin{array}{c}\text { BULK SPESIFIC } \\
\text { GRAVITY AGGREGATE }\end{array}$ & 2.81 & 2.82 & 2.83 & 2.84 & 2.84 \\
$\begin{array}{c}\text { EFFECTIVE SPESIFIC } \\
\text { GRAVITY AGGREGATE }\end{array}$ & 2.85 & 2.85 & 2.86 & 2.86 & 2.88 \\
\hline
\end{tabular}

Hasil pemeriksaan karakteristik pada marshall konvensional yang meliputi Stabilitas, VIM, VMA.

Tabel 5. Nilai Karakteristuk Marshall Konvensional

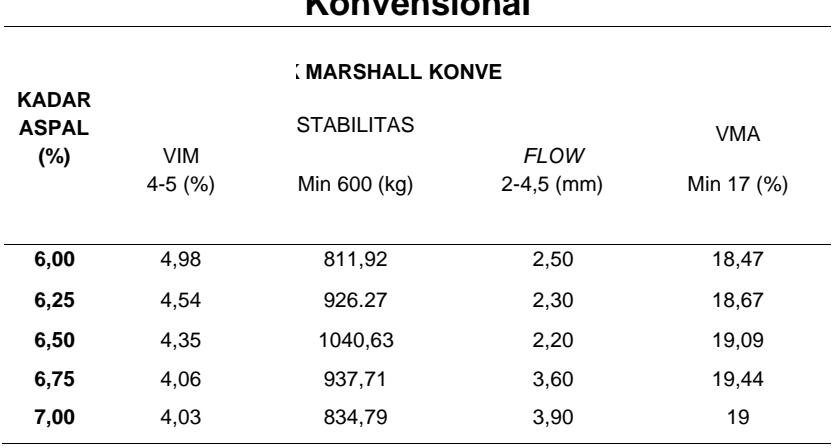

\section{a. Stabilitas}

Nilai stabilitas yang didapatkan pada penelitian ini adalah $857,66 \mathrm{~kg}-937,71 \mathrm{~kg}$. Nilai ini memenuhi persyaratan yang telah ditetapkan. Dari hasilnya dibentuklah grafik hubungan antara nilai kadar aspal seperti pada gambar 3 ini.

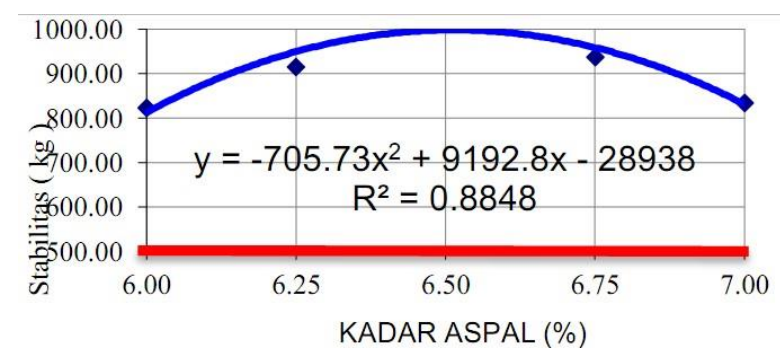

Gambar 3. Hubungan stabilitas dengan kadar aspal

\section{b. VIM (Void In mix)}

kadar aspal yang dipakai pada penelitian ini adalah $6,00 \%-7,00 \%$ pada SMA Kasar didapatkan nilai VIM antara $4,86 \%$ - $4,37 \%$ artinya memenuhi syaratnya kemudian dibuatkanlah grafik seperti dibawah ini. 
Paulus Civil Engineering Journal

E- Jurnal Teknik Sipil UKI-Paulus Makassar

http://ojs.ukipaulus.ac.id/index.php/pcej

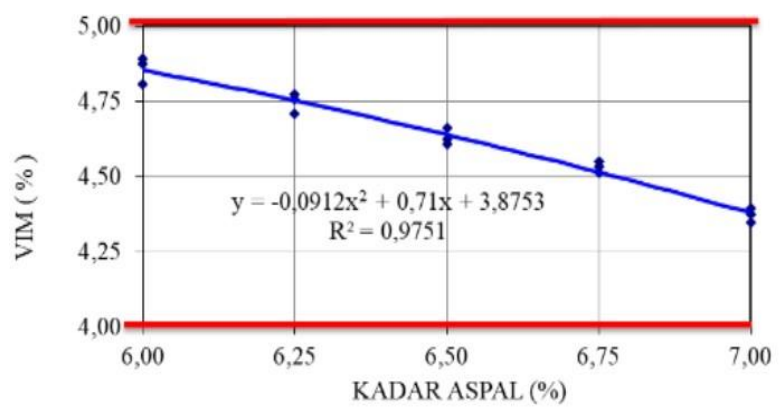

Gambar 4. Hubungan stabilitas dengan kadar aspal

Sehinggah ditarik kesimpulan pemakaiaan aspal yang banyak bias mengisi rongga di agregat. c. Flow

Pemeriksaan flow didapatkan hasil Flow ialah 3,00 $\mathrm{mm}-3,10 \mathrm{~mm}$. Memenuhi syarat dan kemudian di buatkan grafic hubungan terhadap kadar aspalseperti pada gambar 5 .

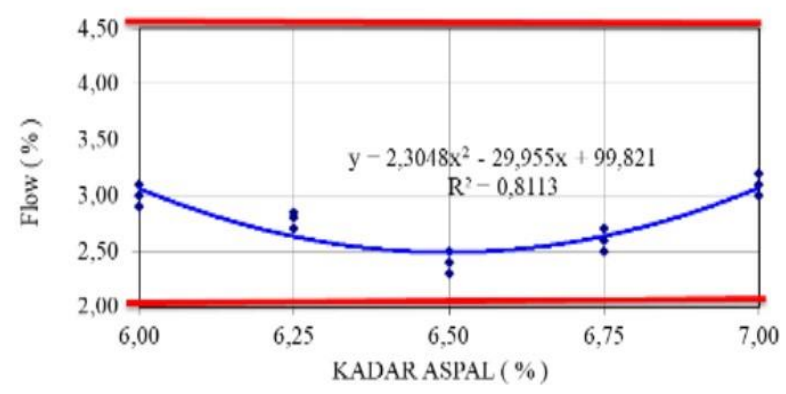

Gambar 5. Hubungn antara flow terhadap kadar aspal

\section{d. VMA (Void in Mineral Agregate)}

Denganmengunakan kadar aspal 6,00\%-7,00\%. Di perole antara $18,38 \%-20,29 \%$ seperti pada tabel 5 , di mana nilai tersebut memnuhi persyaratn. Hal Ini di pengaruhi oleh semakin banyak aspal yang di gunakan, oleh karena fungsi aspal selain menyelimuti aggregat (aspal efektif) juga berfungsi untuk mengisi rongga di antara aggregat dan dalam partikel aggregat.

Pada gambar 6 terlihat bahwa saat aspal yang dipakai dengan jumlah yang besar makarongga yang terisi aspal akan membesar sehinga nilai VMA akan meningkat juga.
Volume 3 No.1, Maret 2021

ISSN Online 2775-4529

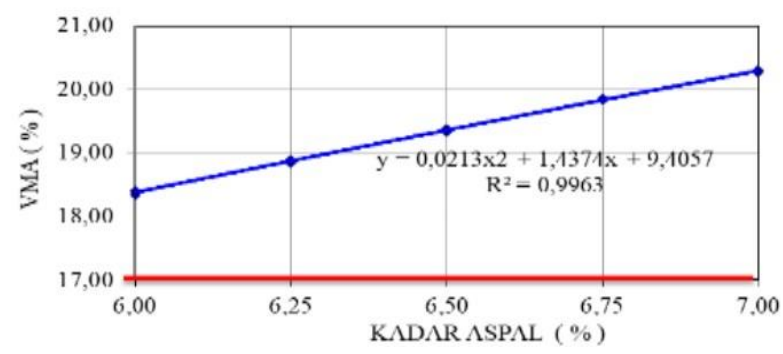

Gambar 6. Hubungan antara VMA dengan kadar aspal 3. Penentuan nilai KOA

Kadar aspal memenuhi semua syaratan atau karakteristik marshalll campran dan kadar aspal praktis tersebut adalah kadar aspal 6,00\% - 7,00\%. Untuk KOA di pilih nilai VIM terbesar atau tinggi yaitu kadar aspal 7,0\%.

\section{Stabilitas Marshall Sisa}

Penelitian ini dilanjutkan dengan membaut benda uji sesuai dengan $\mathrm{KOA}$, yaitu $7,00 \%$ lalu bendauji di rendam selama \pm 24 jam pada suhu $\pm 60^{\circ} \mathrm{C}$.

Tabel 6. Hasil pengujian stabilitas marshall sisa

\begin{tabular}{cccc}
\hline $\begin{array}{c}\text { Kadar } \\
\text { aspal (\%) }\end{array}$ & \multicolumn{3}{c}{ Nilai Stabilitas } \\
& Konvensional & Immersion & SMS \\
\hline 7,00 & 926,27 & 914,84 & 98,77 \\
7,00 & 949,14 & 891,97 & 93,98 \\
7,00 & 937,71 & 880,53 & 93,90 \\
Rata-rata & 937,71 & 895,78 & 95,55 \\
\hline
\end{tabular}

Stabilitas marshall sisa di dapatkan dengan membandingkan stabilitas pada marshall setelah di rendam pada suhu60 ${ }^{\circ} \mathrm{C}$ didalam watetrbath selama 24 jam Dan unntuk stabilitas benda uji Marshall dengan perendaman 30 menit.

Hasil pengujiian marshall Immertion atau stabilitas marshall sisa adalah sebesae 95,90 \% dengan kadar aspal 7,0\%. Hasil stabilitas marshalll sisa ini telah memenuhi syarat spesifikasi umum bina marga 2018 yaitu minimal $90 \%$.

\section{KESIMPULAN}

Karakteristik agregat dari Limbah Nikel Sorowako, Kabupaten Luwu Timur, Aspal Penetrasi 60/70, dan Filler semen dapat digunakan sebagai bahan campuran Stone Matrix Asphalt (SMA) Kasar serta telah memenuhi Standar Spesiiifikasi umum Bina Marga 2018.

Rancangan bahan pada campuran Stone Metrix Asphatl (SMA) Kasar yang digunakan adalah kadar 
Paulus Civil Engineering Journal

E- Jurnal Teknik Sipil UKI-Paulus Makassar

http://ojs.ukipaulus.ac.id/index.php/pcej
Volume 3 No.1, Maret 2021

ISSN Online 2775-4529 aspal yang memiliki nilai optimum yaitu $7,00 \%$ dimana komposisi gradasi agregat yang digunakan ditentukan berdasarkan VIM terkecil dengan memperhatikan jumlah agregat kasar, agregat halus dan berat jenis Filler.

Nilai stabilitas, flow, VIM,VMA memenuhi standar Spesifikai Umum Bina Marga 2018 dan melalui pengujian Marshall Immersion (stabilitas Marshall sisa) pada campuran Stone Matrix Asphalt menggunakan agregat dari limbah Nikel Sorowako Kabupaten Luwu Timur memenuhi standar memenuhi Standar Spesifikasi Umum Bina Marga Tahun 2018.

\section{DAFTAR PUSTAKA}

[1] S. Yuniarti, R. Rachman, dan Alpius, 2020, "Studi Karakteristik Campuran AC-BC Menggunakan Limbah Kantong Plastik

Sebagai Bahan Tambah," Paulus Civ. Eng. J., vol. 2, no. 2, hlm. 70-76.

[2] Sumardi, R. Rachman, dan J. Tanijaya, 2019, "Study of the Use Bagasse Ash as a Filler Replacement to Characteristics Asphalt Concrete," Int. J. Sci. Eng. Sci., vol. 3 , no. 8, hlm. 65-70, doi: 10.5281/zenodo.3408011.

[3] F. Manguma, C. Kamba, dan Alpius, 2020, "Pengaruh Penggunaan Slag Nikel Terhadap Indeks Kekuatan Sisa Campuran HRS-WC," Paulus Civ. Eng. J., vol. 2, no. 3, hlm. 208-215.

[4] C. Kamba dan R. Rachman, 2018, "Marshall Characteristics Test On Hot Rolled Sheet Base Combine Using Nickel Slag For Half Gap Graded," Int. J. Innov. Sci. Eng. Technol., vol. 5, no. 3, hlm. 14-19.
[5] A. Kusuma dan R. Rachman, 2018, "Study Characteristics of Nickel Slag For Gradient Gap on Mixtured Hot Rolled Sheet Base," Int. J. Innov. Sci. Eng. Technol., vol. 5, no. 3, hlm. 8-13.

[6] Utami Arruantasik Demmalino, C. S. W. Lambe, R. Rachman, dan Alpius, 2019,

"Pengujian Slag Nikel Sebagai Pengganti Agregat Pada Campuran HRS-Base,"

Paulus Civ. Eng. J., vol. 1, no. 2, hlm. 20 27.

[7] R. Rachman, 2019, "Karakteristik Campuran HRS - BASE Menggunakan Bubuk Dolomit Sebagai Filler," dalam Konfrensi Nasional Teknik Sipil Ke 13, Banda Aceh, vol. 1, hlm. 420-430.

[8] S. A. Datu, R. Rachman, dan M. Selintung, 2020 "The Effect of Additional Sugar Palm Fibers on the Durability of Mixed Laston ACWC," dalam The 3rd International Conference on Civil and Environmental Engineering (ICCEE), Bali, Indonesia, vol. 419, doi: 10.1088/1755-1315/419/1/012063.

[9] J. Tandibua, R. Rachman, dan J. Tanijaya, 2020, "Study of Laston BC Durability and Permeability Using Coconut Shell Addition Materials," dalam The 3rd International Conference on Civil and Environmental Engineering (ICCEE), Bali, Indonesia, vol. 419, doi: 10.1088/1755-1315/419/1/012035.

[10] Alpius, 2018 "Effects of Additional Rattan Fiber on Hot Rolled Sheet Wearing Course (HRS-WC) Stability," Int. J. Innov. Res. Sci. Eng. Technol., vol. 7, no. 3, Art. no. 3, doi: 10.15680/IJIRSET.2018.0703066.

[11] Direkorat Jenderal Bina Marga, 2018 Spesifikasi Umum Bina Marga 2018 untuk Pekerjaan Konstruksi Jalan dan Jembatan Divisi 6. Jakarta: Kementerian Pekerjaan Umum dan Perumahan Rakyat,

[12] S. Sukirman 2013, Beton Aspal Campuran Panas, Edisi Kedua. Jakarta: Yayasan Obor Indonesia. 